\title{
O ALÉM E A VISÃO DE MUNDO MEDIEVAL: O INFERNO DA VISÃO DE THURKILL
}

\section{Afterlife and medieval world vision: the hell of thurkill's vision}

\author{
Ricardo Boone Wotckoski \\ Doutorando em Linguística pela Universidade de Franca \\ Docente do Claretiano - Centro Universitário \\ rwotckoski@gmail.com \\ ORCID: https://orcid.org/0000-0001-7105-9286
}

\begin{abstract}
Resumo :
No presente artigo, analisa-se o inferno descrito na Visão de Thurkill, relato visionário medieval, a partir da ideia de grande tempo de Bakhtin. Para tanto, retoma-se a literatura precedente na Antiguidade clássica, apocalíptica e apócrifa judaico-cristã e sua conformação com a realidade vivida por sua audiência para, em seguida, descrever a ocorrência de Thurkill como literatura visionária medieval, as características que a circundam e a individualizam como produção sociocultural, embora singular, no contexto em que linguisticamente se constitui sua dimensão de maior relevo na Idade Média, que é o inferno. Ao se ocupar com a dimensão baixa do além e seus condenados, essa produção manifesta-se carnavalizada, invertida e parodiada, permitindo ao estrato social popular, das camadas baixas da sociedade medieval, contemplar, presenciar e regozijar-se com a inversão de posição que o além propicia entre as classes sociais.
\end{abstract}

\section{Palavras-chave: Além-mundo - inferno - literatura visionária medieval - Thurkill}

\section{Abstract:}

In the present article, we analyze the hell described in Thurkill's Vision, a medieval visionary narrative, from Bakhtin's idea of great time. For this, the previous literature in classical, apocalyptic and apocryphal Judeo-Christian antiquity and its conformation to the reality lived by its audience is resumed, to describe then the occurrence of Thurkill as medieval visionary literature, the characteristics that surround and individualize it as a sociocultural production, albeit singular, in the context in which linguistically its most important dimension in the Middle Ages, the hell, is constituted. By dealing with the low dimension of the beyond and its damned, this production manifests itself carnivalized, inverted and parodied, allowing the popular social stratum to contemplate, from the lower levels of medieval society, witness and rejoice with the inversion of position that the afterlife propitiates between social classes.

Keywords: Afterlife world - hell - medieval visionary literature - Thurkill 


\section{INTRODUÇ̃̃O}

O presente artigo pretende aplicar o conceito de grande tempo apreendido da obra de Mikhail Bakhtin (1895-1975) à Visão de Thurkill, relato visionário medieval do século XIII, que representa o ápice do gênero antes de seu declínio. A aplicação do conceito ao relato pressupõe compreendê-lo como manifestação de determinada temática em contexto cultural específico, que requer sua conformação à situação singular de vida de sua audiência, manifesta no próprio gênero do discurso que se utiliza, visando a determinado fim.

Para que assim se demonstre, o artigo foi dividido em três partes. Na primeira, procura-se demonstrar a conformação do relato ao conceito de grande tempo. Partindose da premissa de que o tema que perpassa o grande tempo e que se faz presente na Visão de Thurkill é o além-mundo, o artigo retoma alguns dos gêneros que formataram o tema em épocas precedentes e sua finalidade. Em seguida, o artigo faz uma panorâmica do contexto sociocultural da Idade Média que propiciou o florescimento da literatura visionária medieval e sua perspectiva própria de abordar o além-mundo. Por fim, uma análise do inferno descrito na Visão de Thurkill, seu diálogo com a produção literária antecedente sobre o além, sua singularidade na abordagem do além-mundo e sua pretensão pedagógica ao carnavalizar e inverter a ordem social em sua caracterização do inferno e seus habitantes humanos e transcendentes.

\section{O ALÉM-MUNDO E SUA MANIFESTAÇÃO NO GRANDE TEMPO}

A temática do além-mundo e, em especial, sua dimensão reservada ao castigo dos malfeitores, acompanha a humanidade desde os tempos mais remotos, ressurgindo aqui e ali, transvestida de gêneros para atender as expectativas religiosa e social de diferentes audiências. Ao comentar a relação entre tempo, narrativa e dialogismo em Bakhtin, Machado (1998, p. 33) observa que:

[...] tanto a experiência como a criação são manifestações marcadas pela temporalidade. Apesar da importância do tema, não é de modo sistemático que se pode ter acesso às formulações de Bakhtin sobre o assunto, visto estas se encontrarem disseminadas ao longo de seus estudos sobre os géneros, o 
cronotopo, a polifonia. A falta de sistematização, contudo, não é fortuita. $\mathrm{O}$ tempo na teoria do dialogismo não é um constituinte estrutural da narrativa, pelo contrário, a narrativa e, consequentemente, os gêneros, são instâncias estéticas de representação do tempo. Visto por esse viés, a noção de tempo distancia-se das abordagens mais divulgadas sobre o assunto, sobretudo porque desconhece as fronteiras entre a ética e a estética.

O retorno de determinada temática, portanto, permite o diálogo entre homens e culturas, promovendo uma intersecção, mas também uma resposta que insere nova perspectiva ao tema, ao mesmo tempo em que toma lugar no grande tempo, processo que se manifesta não só na individualidade, mas que abarca a noção e uso dos gêneros, pois:

para Bakhtin, não só as obras individuais mas também os gêneros podem ser entendidos como forma de pensamento, uma vez que cada gênero narrativo manifesta um modo específico de entender o tempo. Nesse sentido, as várias questões sobre o tempo são respondidas por diferentes gêneros [...]. A discussão sobre o gênero não deixa de ser análise e teorização sobre obras específicas que levantam questões humanas fundamentais (MACHADO, 1998, p. 39).

Essa participação das culturas por meio de gêneros que melhor emancipam a visão de mundo é perceptível, por exemplo, pela abordagem que o Ocidente promoveu sobre o além-mundo ao longo de sua história, o que inevitavelmente culminará na Visão de Thurkill, em torno da qual se move o presente trabalho, pois a literatura visionária medieval sobre o além-mundo abarca um número expressivo de relatos, em que um visionário deixa seu corpo e, em espírito, empreende uma jornada ao mundo dos mortos acompanhado por um guia, geralmente anjo ou santo, com permissão para testemunhar onde e em que condições vivem os mortos no além. Terminada a viagem, o visionário regressa com a incumbência de alertar seus iguais a respeito do iminente perigo de terminarem a eternidade no espaço reservado ao castigo dos maus.

Embora encontre na Idade Média campo fértil, os relatos de jornadas ao outro mundo já eram comuns na Antiguidade. Estão presentes, por exemplo, na literatura clássica e na tradição judaico-cristã. Para exemplificar a presença da temática na literatura clássica, podemos citar Homero ${ }^{1}$, Virgílio $^{2}$ e Plutarco ${ }^{3}$. Este último, num ensaio intitulado Sobre os atrasos da vingança divina, narra a jornada ao além de um 
homem identificado como Trespesius, malandro que morre após uma queda e volta à vida três dias depois, transformado pela experiência de conhecer o além-mundo (POTTHOFF, 2017).

No contexto da tradição judaico-cristã, é na literatura apocalíptica que proliferou, no período intertestamental ${ }^{4}$ e nos primeiros séculos do cristianismo que encontramos os relatos que mais se aproximam das visões medievais do além-mundo. A apocalíptica, como sintetiza de modo singular Collins (1998, p. 5), diz respeito a:

um gênero de literatura revelatória com uma estrutura narrativa, em que a revelação é mediada por um ser de outro mundo para um receptor humano, revelando uma realidade transcendente que é simultaneamente temporal, na medida em que prevê a salvação escatológica, e espacial na medida em que envolve outro mundo sobrenatural.

Como exemplo, podemos citar o Apocalipse de João, livro canônico do Novo Testamento. Nele, João de Patmos é instado a escrever e compartilhar com as sete igrejas da Ásia Menor a revelação que vê e escuta de um anjo.

Muitas são as lacunas deixadas pelos livros canônicos do Novo Testamento a respeito do além, em especial no que diz respeito ao inferno. É a literatura apócrifa, no entanto, que procura suprir a falta de informações do texto bíblico e, consequentemente, influenciará substancialmente o imaginário ocidental sobre o tema. Observa Morgan (2007) que, ao fazê-lo, recorre principalmente à literatura clássica grega. Dentre a extensa produção apócrifa relacionada ao além podemos citar o Apocalipse de Pedro e o Apocalipse de Paulo.

O Apocalipse de Paulo ou Visio Pauli é o relato de jornada ao além-mundo de maior expressão, dentre as primeiras do gênero. A visão se propõe a preencher uma lacuna deixada pelo Apóstolo Paulo ao mencionar uma jornada ao paraíso por ele empreendida, na sua Segunda Carta aos Coríntios, versículos 2 a $4 .^{5}$ Entre os pesquisadores é praticamente unânime que a versão do Apocalipse de Paulo que chegou até nós pertence ao IV século. No relato, ao ser arrebatado aos céus, o visionário observa as almas que, ao deixarem seus corpos, comparecem perante Deus e são recompensadas ou castigadas, de acordo com os atos praticados em vida. A narrativa faz 
também uma descrição do paraíso e dos tormentos dos condenados ao inferno, cujo panorama descrito muito se assemelha ao de outra visão do além que a antecedeu: o Apocalipse de Pedro.

Na tradição apócrifa do Novo Testamento há três apocalipses atribuídos ao Apóstolo Pedro. O texto sobre o qual se faz referência neste trabalho é o descoberto em 1887, em Akhmin, Egito, cuja versão etíope mais completa teve sua descoberta posteriormente. Esse apocalipse gozou de considerável prestígio entre comunidades cristãs dos primeiros séculos, constando inclusive como canônico em algumas listas desse período. Todavia, nos séculos posteriores foi relegado à condição de apócrifo, mas continuou a exercer influência sobre o imaginário cristão ocidental a respeito do alémmundo, para além da Antiguidade, estendendo seu alcance como inspiração a numerosas visões posteriores. No relato, seu protagonista, supostamente o Apóstolo Pedro, descreve uma jornada ao inferno e ao céu. A narrativa começa com Pedro e os demais apóstolos no Monte das Oliveiras, ouvindo o discurso apocalíptico de Jesus, o mesmo narrado no Evangelho Segundo Marcos, capítulo 13. Na sequência, Jesus responde à indagação do suposto apóstolo Pedro sobre o juízo final, descrevendo os terríveis acontecimentos que acompanharão a destruição do mundo pelo fogo. Detalha ainda alguns dos tormentos eternos reservados aos condenados ao inferno $\mathrm{e}$ as bemaventuranças sem fim dos salvos.

Embora fundamentais para a configuração do além-mundo que se consolidará na Idade Média, somente no século VI é que o gênero visão do além-mundo se consolida com a publicação de Diálogos, de Gregório Magno, ${ }^{6}$ obra em que inseriu, no quarto volume, vários relatos visionários, que serviram de motivação e modelo para o registro de relatos que se seguiram. Morgan (2007) assinala que o caráter didático que envolve a literatura visionária sofre uma mudança abrupta, durante o Império Carolíngio (século IX). A sátira é introduzida ao gênero, propiciando a crítica social. É comum encontrar em relatos visionários, desse período e em posteriores, o castigo infernal sendo aplicado a figuras importantes, como papas, bispos, padres, reis, nobres, juízes, dentre outros.

O ponto alto do gênero visionário em termos de quantidade e de amplitude dá-se no século XII. Morgan (2007) afirma que, antes de didática ou crítica social, a visão de além-mundo alcança, nesse tempo, a condição de literatura. Nesse período, tende a diminuir o número de relatos atribuídos a figuras da alta hierarquia da Igreja e em que 
os visionários sejam clérigos. Crescem, portanto, as narrativas de monges e abades que trazem como visionários camponeses, cavaleiros, crianças e, com menor frequência, os próprios monges. Dentre as visões de além-mundo desse período, a mais conhecida e, talvez mais estudada, é a Visão de Túndalo. A última é a Visão de Thurkill, datada de 1206. Todavia, a coletânea existente continuou circulando em enciclopédias e livros de histórias pela Europa cristianizada, o que indica, conforme observa Morgan (2007), que a tradição continuou viva por algum tempo.

Essa revisão panorâmica da recorrência da temática em torno do além-mundo permite que se reconheça sua constância ao longo da história do Ocidente, ancorada em diferentes gêneros, em diferentes épocas e culturas. Grosso modo, percebe-se, por exemplo, que a Antiguidade clássica dialoga com o tema em epopeias que abordam a questão dentro do determinismo imputado sobre os gregos pelos deuses, uma realidade transcendente com forte impacto sobre o mundo imanente. A literatura apocalíptica judaico-cristã, influenciada por culturas do oriente próximo, retoma a dimensão transcendente num período de dominação estrangeira, para consolar os fiéis por meio da noção de que a realidade humana é decidida sim na dimensão transcendente, mas que Deus está no comando e tudo caminha de acordo com seu plano, que culminará com a sua intervenção direta na história com a chegada do Messias, no Juízo Final. A literatura apocalíptica chamada apócrifa, ${ }^{7}$ por sua vez, propõe-se a responder lacunas deixadas pelos textos bíblicos no que se refere ao além. As visões do além-mundo, que floresceram na Idade Média, por sua vez, servem ao propósito, num primeiro momento, de incutir o temor da morte sem penitência e obras meritórias. Contudo, passam por um processo de ressignificação que inclui em seu discurso a crítica social e, em seu ponto alto, chegam à condição de literatura, atingindo seu ápice com a Divina Comédia, considerada a obra inaugural da língua italiana. Antes, porém, o final dessa efervescência visionária contou com uma de suas manifestações de maior preenchimento de elementos visionários: a Visão de Thurkill, da qual se ocupará o presente trabalho na sequência. Antes, porém, convém uma contextualização dessa sociedade, que retoma o tema do mundo dos mortos. 


\title{
IDADE MÉDIA E VISÃO DE MUNDO: O IMAGINÁRIO MEDIEVAL
} SOBRE O ALÉM

A teologia cristã é a grande ciência da Europa medieval cristianizada e sua antropologia é universalista e determinista com relação à origem, natureza e destino do ser humano: criado por Deus, mas corrompido pelo pecado, tem diante de si dois destinos: a condenação eterna ou salvação de sua alma imortal, após a morte terrena.

\begin{abstract}
Vivendo num mundo agrícola, em que se percebe cotidianamente como alguns seres precisam morrer para que outros possam viver, convivendo com a constante ameaça da fome, das epidemias e das guerras, os medievais sentiam a onipresença da morte, mas isso não os incomodava. Eles tinham dela uma visão natural, tranquila, diferente da de seus descendentes dos séculos seguintes. Como o cristianismo ensina que a morte é o começo da vida eterna, e não o fim definitivo, chegado o momento as pessoas procuravam se preparar. A grande tragédia não era morrer, mas morrer inesperadamente, sem ter confessado, recebido os sacramentos, feito doações e esmolas, estabelecido o testamento. Tinha-se consciência e resignação pelo fato de que o destino das espécies vivas é morrer. A morte nivela os homens e mostra o despropósito de seu orgulho e suas riquezas (FRANCO JÚNIOR, 2001, p. 188).
\end{abstract}

Le Goff (1989) observa que a Idade Média é o período em que a dimensão negativa do homem é mais acentuada, sobretudo dos séculos IV ao XII, sendo que, especialmente dos séculos XII a XV, desenvolve-se uma progressiva ênfase no Cristo da Paixão que, como o homem do medievo, sofre, mas o padecimento humano tem causas transcendentais, cujas origens estão na revolta de Satanás e na queda dos primeiros seres humanos em pecado. Todavia, sua luta terrena não é o fim, mas apenas o começo e culminará no além-mundo, que será eterno. Daí, mais importante sofrer o presente e ganhar a eternidade no paraíso que passar o resto da imortalidade no inferno.

Esse homem, que o dogma e a prática do cristianismo medieval tendem a transformar em tipo universal, reconhecível seja qual for a sua condição, é um ser complexo. Em primeiro lugar, é constituído pela união contrastante entre a alma e o corpo. Qualquer que tenha sido o desprezo que o cristianismo medieval nutrisse pelo corpo, «esse abominável revestimento da alma», segundo Gregório Magno, o homem medieval vê-se obrigado - e não apenas pela sua própria experiência de vida, mas também pelos ensinamentos da Igreja - a viver na dualidade corpo/alma. Cada parte do 
corpo, cada sintoma carnal é um sinal simbólico que remete para a alma. É através do corpo que se concretiza a salvação ou a condenação, ou melhor, a alma atinge o seu destino através do corpo (LE GOFF, 1989, p. 13).

Para Le Goff (1989), a dicotomia corpo/alma reverbera nas demais instâncias da sociedade medieval e toma forma, por exemplo, nas oposições superior/inferior; clérigos/leigos; poderoso (rico)/pobre, que caracterizam a sociedade desse período. A Igreja, por sua vez, torna-se o grande árbitro entre o homem pecador e Deus. Institui para tanto diversos ritos considerados purificadores das almas, preparando-as para a passagem deste mundo para o além. Ascende nesse período a veneração aos santos, que se tornam mediadores entre a dimensão terrena e a espiritual. Por fim, surge a ideia do purgatório, o que permite que a Igreja estenda seu domínio também sobre o além, requerendo dos fiéis missas e orações em prol das almas que necessitam purgar seus pecados, no purgatório, para então, finalmente, adentrar no paraíso.

O purgatório é, se assim se pode dizer, uma sala de espera destinada aos pecadores médios e ordinários (mediocres, em latim), que não podem ir diretamente para o paraíso, mas que também não merecem o inferno. Quase todo cristão podia então pensar que passaria por esse purgatório para limparse de suas faltas. Era reconfortante. Todos supunham que poderiam escapar do inferno. Mas representava-se (sic) muito mal esse lugar vago e cinzento onde a alma suspirava por estar tão próxima de Deus, sem entretanto chegar até Ele. A visão que se construiu dele é a de um inferno menos terrível, porém de qualquer modo temporário (LE GOFF, 2005, p. 131).

É, pois, nesse contexto, que as visões medievais sobre o além-mundo ganham maior relevo. Compiladas entre relatos considerados históricos de autores como Gregório de Tours (538-594), Beda o Venerável (675-735) e das hagiografias de Gregório Magno (540-604) transitam pelo continente, imprimindo maior concretude ao além, em especial, ao inferno. Essas visões do além-mundo configuram-se como importante fonte para se entender o imaginário medieval. Isso porque, diferentemente do que se pode pensar, não representavam focos de alienação, mas, como argumenta Le Goff (1989, p. 14), “as concepções medievais do homem o integravam, de uma maneira ou de outra, na sociedade". O tema do além-mundo, portanto, retorna na Idade Média, em diálogo com a vasta produção antecedente, mas em sintonia com a visão de mundo 
que configura a Idade Média ocidental. Reflete, sim, como o homem desse período digere e ressignifica o além. Dessa forma, a literatura visionária não se apresenta na Idade Média como mera continuação ou reprise do que já se manifestara em épocas passadas. Embora retome e dialogue com o passado, configura-se a partir e na cultura presente. Segundo Bakhtin (1998, p. 100):

\begin{abstract}
a língua não é um sistema abstrato de formas normativas, porém uma opinião plurilíngue concreta sobre o mundo. Todas as palavras evocam uma profissão, um gênero, uma tendência, um partido, uma obra determinada, uma pessoa definida, uma Geração, uma idade, um dia, uma hora. Cada palavra evoca um contexto ou contextos, nos quais ela viveu sua vida socialmente tensa; todas as palavras e formas são povoadas de intenções. Nela são inevitáveis as harmônicas contextuais (de gêneros, de orientações, de indivíduos).
\end{abstract}

Recai sobre o gênero, portanto, uma enunciação da qual participam elementos de fora do texto e que colaboram para a forma e o conteúdo com que o além-mundo, nesse momento da história, se manifesta. Argumentando sobre a estilística adequada para o estudo da literatura, Bakhtin (1998, p. 106) afirma que:

\begin{abstract}
A única estilística adequada para esta particularidade do gênero romanesco é a estilística sociológica. A dialogicidade interna do discurso romanesco exige a revelação do contexto social completo, o qual determina toda a sua estrutura estilística, sua "forma" e seu "conteúdo", sendo que os determina não a partir de fora, mas de dentro; pois o diálogo social ressoa no seu próprio discurso, em todos os seus elementos, sejam eles de "conteúdo" ou de "forma".
\end{abstract}

Evidencia-se, portanto, mais uma vez, que, embora as visões de além-mundo retomem o mundo dos mortos, não o fazem como em outros momentos, pois o tempo e mesmo o espaço são outros e contribuem, de maneira particular, para o imaginário de então. Ancorando-se nessa perspectiva da singularidade da enunciação, na sequência, apresenta-se a ocorrência de uma visão medieval do além-mundo que circulou no medievo inglês. 


\section{A VISÃo DE THURKILL E SUAS RELAÇÕES DIALÓGICAS NA PRODUÇÃO DE SENTIDO}

Thurkill ou Thurkilli, em latim, como última expressão significativa das visões de além-mundo produzidas na Idade Média antes da Divina Comédia, de Dante Alighieri, articula as descrições do além-mundo que a precederam, configurando-se como síntese de um gênero já consolidado em seu tempo. A visão retoma, portanto, o além-mundo num diálogo com as manifestações anteriores, em especial as heranças da Antiguidade clássica, da literatura apocalíptica judaico-cristã, da literatura apócrifa cristã dos primeiros séculos de nossa era e da própria produção visionária medieval, não deixando, por outro lado, de se apresentar como manifestação singular, de um camponês dos arredores de Londres, de uma dada sociedade envolta por uma visão de mundo predominante e em constante reelaboração, face a dinâmica dialógica que permeia as relações humanas.

A versão da Visão de Thurkill a que se fará referência nesse artigo é a tradução empreendida por Wotckoski (2013) do texto em latim disponível em Flores Historiarum, volume de crônicas de Roger de Wendover $^{8}$ e sua versão para o inglês moderno, de 1841, editada por H. O. Coxe. O cronista situa o relato no vilarejo de Tunsted, Bispado de Londres, ao cair da noite ${ }^{9}$ do dia 27 de outubro de 1206, véspera do Dia dos apóstolos São Simão e São Judas. O guia de Thurkill pelo além-mundo será São Juliano, ${ }^{10}$ enviado de São Tiago, ${ }^{11}$ de quem o visionário era devoto. Além disso, Thurkill é descrito como simples camponês, de poucos recursos, mas hospitaleiro, piedoso, orante e praticante da fé cristã.

A visão, portanto, situa-se no contexto de um diálogo implícito com a sociedade feudal do Baixo Medievo e de modo explícito com a religião dominante, equilibrandose, por meio do redator, entre os dogmas oficiais da Igreja e a fé popular praticada pelas pessoas simples, sem letramento e sem formação teológica. Thurkill, um camponês pobre, lavrador da terra, provavelmente subjugado a um senhor feudal, a quem devia obediência e tributos, e à própria Igreja, a quem devia o dízimo de sua lavoura, é o privilegiado com a visão do além. 
São Juliano aparece a Thurkill quando este ainda estava em sua lavoura, para avisá-lo da jornada a que seria conduzido logo mais, à noite, quando, deixando seu corpo estirado sobre a cama, seu espírito acompanharia o santo ao além-mundo, cuja porta de entrada seria a Basílica de Santa Maria ${ }^{12}$ que, segundo São Juliano, ficava no centro do mundo. Ali, guia e visionário encontram-se com São Tiago e São Domingos. ${ }^{13}$ Sobre a presença da hagiografia da Igreja na Visão de Thurkill, Golin e Wotckoski (2015) chamam atenção para o fato de que, embora circunscrita à Bretanha, a visão, por meio de referências aos santos e à Basílica de Santa Maria, dialoga e explicita sua relação com a Igreja oficial de Roma.

Já na Basílica de Santa Maria, o visionário é conduzido por seu guia ao fogo purgatório, ${ }^{14}$ local administrado por São Nicolau, ${ }^{15}$ reservado à purgação dos pecados daqueles que porventura precisassem expiar algum pecado antes de adentrar no Monte da Alegria, localização do paraíso, descrito como uma exuberante basílica e um maravilhoso jardim. Depois, de conhecer as provações do fogo purgatório, guia e visionário regressam à entrada do além, onde São Miguel Arcanjo, ${ }^{16}$ São Pedro e São Paulo são responsáveis por recepcionar as almas recém-chegadas ao além-mundo. $\mathrm{Na}$ entrada do inferno, que ficava a norte da basílica, São Paulo e o Diabo disputam as almas dos pecadores, aferindo sua culpa por meio de uma balança. ${ }^{17}$ Quando esta pendia para o lado do apóstolo, a alma era conduzida ao purgatório para sua purgação, quando pendia para o lado do Diabo, no entanto, era "em meio a gargalhadas que os demônios lançavam os espíritos na fornalha profunda e ardente, que estava aos pés do diabo" (WOTCKOSKI, 2013, p. 141). Outro evento regado por gargalhadas dos demônios segue ao já mencionado:

\footnotetext{
Ao anoitecer do sábado, estando São Domingos e São Juliano na basílica, veio do norte certo diabo que galopava em meio a gritos e gargalhadas um cavalo preto, que rodopiava em alta velocidade pelo lugar. Enquanto isso, muitos dos espíritos maus saíram ao seu encontro com danças e gargalhadas, rodeando a presa.
}

Questionado sobre a montaria, o diabo explica tratar-se de um nobre inglês, que morrera na noite anterior, sem receber a absolvição e a eucaristia. No entanto, a principal falta do nobre em vida, transformado em montaria como era permitido aos 
demônios fazerem com os danados, segundo o diabo, fora de natureza social e não religiosa: "a crueldade para com seus servos, levando muitos deles à extrema exaustão, instigado, sobretudo, por sua esposa, que sempre o incitava à crueldade" (WOTCKOSKI, 2013, p. 141).

A cena descrita, além de resgatar a exploração dos pobres, já comum nas visões tardias, também revela uma inversão da ordem, um contraste entre a solenidade até então descrita e o riso fácil que acompanha o revés que sofrem os danados ao entrarem no inferno. Um condenado é arrastado em meio a gargalhadas ao inferno. Um nobre inglês converte-se, de saída, em diversão para o demônio que o transformara em animal de montaria. Nesse aspecto, a visão dialoga com elementos próprios da literatura cômica popular medieval a que Bakhtin faz referência em duas obras fundamentais: A cultura popular na Idade Média e no Renascimento: o contexto da obra de François Rabelais (1987) e Problemas da Poética de Dostoiévski (1981). Ao comentar o lugar do riso na cultura do medievo, afirma o filósofo russo:

\begin{abstract}
$\mathrm{O}$ mundo infinito das formas e manifestações do riso opunha-se à cultura oficial, ao tom sério, religioso e feudal da época. Dentro da sua diversidade, essas formas e manifestações - as festas públicas carnavalescas, os ritos e cultos cômicos especiais, os bufões e tolos, gigantes, anões e monstros, palhaços de diversos estilos e categorias, a literatura paródica, vasta e multiforme, etc. - possuem uma unidade de estilo e constituem partes e parcelas da cultura cômica popular, principalmente da cultura carnavalesca, una e indivisível (BAKHTIN, 1987, p. 3-4).
\end{abstract}

Observa-se também, na descrição do inferno e seus habitantes, a conformação dessa parte da visão à literatura cômica medieval, que tinha como principal característica a paródia de textos sacros (parodia sacra), que circulavam em paralelo às paródias laicas que "escarneciam do regime feudal e sua epopeia heroica" (BAKHTIN, 1987, p. 13). Fiorin (2006), ao propor uma sistematização dos postulados de Bakhtin sobre a inversão da ordem e o riso a partir de sua relação com a cultura popular e o carnaval, explicita que:

Ao esforço centrípeto dos discursos de autoridade opõe-se o riso, que leva a uma aguda percepção da existência discursiva centrífuga. Ele dessacraliza e relativiza os discursos do poder, mostrando-os como um entre 
muitos e, assim, demole o unilinguismo fechado e impermeável dos discursos que erigem como valores a seriedade e a imutabilidade, os discursos oficiais, da ordem e da hierarquia (FIORIN, 2016, p. 89).

A ruptura com a sobriedade e a solenidade aprofunda-se ainda mais dentro do espaço infernal. Lá, como é costume, nas noites de domingo, os demônios assistem com algazarra os danados encenarem e sofrerem os castigos por seus pecados praticados em vida. Ali a licença para a inversão é permitida até aos santos, pois São Juliano e São Domingos, enganando o diabo, levam secretamente Thurkill ao lugar de danação eterna para bisbilhotar a encenação infernal. Depois de serem advertidos pelo demônio a não levarem consigo o camponês, segue a narrativa:

\begin{abstract}
Assim, os dois santos seguiram o demônio, levando Thurkill em segredo. Subiram para o norte até que avistaram, na baixada, uma enorme casa velha e de paredes escuras. Do lado de dentro havia um grande número de arenas com cadeiras enfileiradas, construídas com aros de ferro fundido e totalmente cobertas de pregos. Nelas sentavam-se pessoas de diferentes condições sociais e de ambos os sexos, que eram perfuradas pelos pregos abrasados e presas por todos os lados por barras de ferro. O número de cadeiras e de pessoas era tão grande que ninguém poderia contá-las (WOTCKOSKI, 2013, p. 142)
\end{abstract}

A inversão operada no inferno descrito na visão também se dá pela condição privilegiada dos demônios que, segundo a tradição cristã, não são administradores do inferno, mas seus prisioneiros, situação diversa da visão, que permite aos demônios até a sensação de prazer, enquanto opera a inversão da ordem oficial da Igreja e da sociedade feudal, atingindo o grotesco por meio dos tormentos e da deformação corporal infligida aos danados em ato contínuo pela eternidade. Afastada, portanto, do que é o socialmente constituído, a descrição do inferno dessa visão aproxima-se ainda mais da inversão carnavalizada.

O carnaval é constitutivamente dialógico, pois mostra duas vidas separadas temporalmente: uma é a oficial, monoliticamente séria e triste, submetida a uma ordem hierarquicamente rígida, penetrada de dogmatismo, temor, veneração e piedade; outra, a da praça pública, livre, repleta de riso ambivalente, de sacrilégios, de profanações, de aviltamentos, de inconveniências, de contatos familiares com tudo e com todos (FIORIN, 2016, p 94). 
Os castigos infligidos aos danados seguem, na visão, uma categorização que leva em conta sua posição social em vida. Representam seus pecados e são violentamente torturados um homem vaidoso, um padre desonesto e indolente, um soldado assassino, um juiz corrupto, um casal de adúlteros, caluniadores, comerciantes desonestos com os pobres, ladrões, incendiários e violadores de lugares sagrados. Cada qual ao encenar os pecados praticados em vida, sofria grotesca violência corporal. O castigo dos adúlteros é representativo da intensidade com que eram atormentados os danados.

[...] um casal de adúlteros foi arrastado à presença dos furiosos demônios. Ali representaram a causa de sua ruína: suas vergonhosas obscenidades e relação sexual. Foram, então, amaldiçoados pelos demônios e, como se tomados por um frenesi, começaram a dilacerar um ao outro, convertendo o amor aparente com que se entretinham antes, em crueldade e ódio. Seus membros foram despedaçados pela multidão furiosa a sua volta e sofreram a mesma punição dos que os haviam precedido. Todos os fornicadores presentes foram atormentados do mesmo modo. E a intensidade de seu sofrimento era tão grande que a pena deste escritor não é suficiente para descrevê-la (WOTCKOSKI, 2013, p. 144).

Nesse ambiente de dor extrema, em que a liturgia é substituída pelo palco dos horrores, deparamo-nos com o inferno carnavalizado. O inferno ensinado pela religião oficial, instrumento de coerção, converte-se numa encenação popular, em que os opressores assumem o lugar dos oprimidos. Como pontua Discini (2006, p. 55), o inferno carnavalizado "testemunha a permutação do alto e do baixo ou a lógica da inversão, própria à cultura popular: os grandes são destronados, os inferiores são coroados". Além disso,

A carnavalização constrói um mundo utópico em que reinam a liberdade, a igualdade, a abundância, a universalidade. Ao mesmo tempo, opera com a categoria da excentricidade, onde as coisas estão às avessas (FIORIN, 2016, p. 105).

É o mundo às avessas que encontramos nessa visão em que os poderosos do mundo dos vivos, no mundo dos mortos, oscilam entre sua posição social e a zombaria e 
humilhação da tortura, da vida à morte e da morte à vida, por meio de castigos que nunca têm fim, pois, no mais, os danados se revezam em caldeirões, num contínuo sofrimento circular, que vai da dilaceração do corpo à sua reconstituição e vice-versa.

\begin{abstract}
Depois disso, Thurkill viu quatro arenas perto da entrada do inferno. A primeira contendo inumeráveis fornalhas e grande variedade de caldeirões cheios até a borda com piche escaldante e outras substâncias derretidas. Neles, os espíritos foram amontoados e aferventados. Com a erupção da fervura, as suas cabeças, semelhante à cabeça de peixe preto, eram impulsionadas umas para fora e outras para dentro. A segunda arena continha caldeirões semelhantes aos primeiros, mas cheios de neve e gelo, nos quais os espíritos eram torturados com frio terrível e agonia insuportável. Os caldeirões da terceira arena estavam cheios de água sulfurosa escaldante e outras substâncias, com uma fumaça fétida. Ali eram torturados especificamente os espíritos que morreram na impureza de sua luxúria. A quarta arena continha caldeirões cheios de água muito escura e salgada. Seu sabor amargo instantaneamente tiraria a casca de qualquer tipo de madeira nela jogada. Fervendo incessantemente nesses caldeirões estava uma multidão de pecadores, assassinos, ladrões, assaltantes, feiticeiras e homens ricos que oprimiram seus semelhantes pela exortação. Os servos da iniquidade, de pé, ao seu redor, pressionavam-nos, juntando-os dentro do caldeirão, de modo que não pudessem escapar do calor do líquido fundido. Os que haviam fervido por sete dias nessa gordura, no oitavo, eram mergulhados no frio extremo do caldeirão da segunda arena. Por outro lado, os torturados no frio eram colocados no líquido escaldante. Da mesma forma, os que tinham sido fervidos na água salgada eram torturados no cheiro fétido. Os demônios providenciavam essa troca de caldeirão ininterruptamente a cada oito dias (WOTCKOSKI, 2013, p. 145).
\end{abstract}

A rotina infernal, portanto, mostra os danados numa contínua ambivalência, que oscila entre morte e vida, sendo as escórias do nascimento e da morte, de que fala Fiorin (2006), aqui representadas pela desagregação corporal, deformidades e monstruosidade, mas que não findam. Ao final do processo, voltam as almas a seu estado inicial para novamente passarem pelo processo de mortificação por meio das grotescas torturas a elas infligidas pelos demônios.

Morgan (2007) corrobora a ambivalência presente nessa descrição ao observar que os caldeirões com substâncias aquecidas ou resfriadas ao extremo, a partir do século XII, passam a compor o cenário infernal, como símbolo das condições dos danados, em oposição aos salvos, que são representados na iconografia medieval como aqueles que se encontram "no seio de Abraão"18. Esse elemento, portanto, traz à memória do 
imaginário popular da época as cenas dramáticas dos danados fervendo em substâncias podres, aquecidas ou frias, comuns na arte sacra.

Além disso, há uma inversão no que se refere ao conteúdo da enunciação: enquanto na literatura apocalíptica o enunciado era de natureza positiva, mostrando que, no futuro, o povo escolhido testemunharia a vitória pela intervenção divina, empenhando-se na tentativa de despertar o sentimento de esperança, na literatura visionária medieval, sua natureza é negativa. $\mathrm{O}$ inferno e seus castigos são descritos em minúcias, ocupando considerável parte do relato, que deve servir de alerta ao visionário e a seus posteriores interlocutores quanto à condição eterna dos danados. No lugar da esperança a que a apocalíptica se propõe a instar, o medo do inferno e seus horrores é a tônica do gênero visionário medieval. ${ }^{19}$

Em tudo isso, mais que a representação do inferno como tema que se deve descrever em termos de baixa cultura, reservando-se ao paraíso uma seleção elevada de signos próprios da cultura socialmente prestigiada, o inferno de Thurkill opera, por meio da condição invertida em que se encontram as personagens danadas e os demônios, a crítica à hipocrisia e à corrupção oculta na aparente superioridade dos poderosos da época. Nesse particular, a camada socialmente excluída ou desfavorecida, numa linguagem própria de sua condição, pode se unir aos demônios do inferno, regozijandose com o destronamento da classe prestigiada e sua patética encenação infernal. O juízo final como espetáculo, acessível ao mais simples, é antecipado pela tradição popular, num lampejo do futuro escatológico em que os maus, dentre eles os poderosos, serão rebaixados diante de todos, o que nos conduz de volta à literatura apocalíptica judaicocristã. Lá, as nações que oprimiam o povo escolhido, no final dos tempos, pela intervenção de Deus na história, seriam destronadas, inaugurando-se uma nova era de felicidade da nação eleita. Na Idade Média, o padrão repete-se, mas na esfera pessoal, ressaltando a responsabilidade individual de cada um por seus atos. A salvação é pessoal, cada um responderá individualmente perante o tribunal divino. Dessa forma, a visão medieval reelabora o tema do além-mundo e já antecipa sua concretização futura, na metafórica relação paradoxal da sociedade e sua aparente ordenação cristã.

De volta à Visão de Thurkill, depois de conhecer o ciclo dos caldeirões, o camponês é conduzido de volta à entrada do além-mundo para, então, conhecer o paraíso, cuja aparência solene e ritual se manifesta na descrição dessa dimensão do além 
nos termos de uma exuberante basílica e um bucólico jardim perfumado. Acordado por seus parentes, o camponês torna-se intrépida testemunha do que viu e ouviu em sua jornada ao mundo dos mortos.

\section{CONSIDERAÇÕES FINAIS}

$\mathrm{O}$ além-mundo, mesmo que em diferentes perspectivas, de acordo com as preocupações de cada época, faz parte do imaginário das culturas desde tempos remotos. Sua abordagem em diferentes gêneros, impulsionados pelo contexto de seu público, pode ser consultada em diferentes momentos da história. No caso do Ocidente, o além-mundo configurou-se como ponto central de sua cultura influenciada pela literatura religiosa de origem judaica e, posteriormente, a cristã.

O inferno, essa dimensão reservada aos condenados à danação eterna, atinge sua configuração na Idade Média, época em que a literatura visionária dá a esta dimensão do além maior concretude, em termos espaciais e dos castigos infligidos pelos demônios aos danados. Dialogando com a literatura precedente, mas configurada de acordo com o momento histórico de sua audiência, essa literatura revelatória, voltada a imprimir o medo dos tormentos infernais eternos, passou por uma evolução, que resultou em seu reconhecimento como forma literária, cuja crítica à sociedade medieval e suas contradições já se pode observar em sua produção tardia, culminando na Divina Comédia, obra basilar da literatura italiana.

Nesse contexto, a Visão de Thurkill manifesta-se como relato visionário, em que o inferno e os castigos aplicados a personagens representativos da sociedade medieval contribuem com a consolidação do gênero. A inversão da situação da classe dominante que, no inferno, sofre as penas infligidas por demônios que gargalham e zombam de seus torturados, marca a carnavalização do inferno, que permite à classe socialmente excluída, mesmo que por breve lapso de tempo, gargalhar como os demônios, daqueles que em vida são seus algozes.

É no inferno, portanto, que se dá a inversão da ordem; o riso e o deboche caracterizam os demônios, enquanto castigam os danados conforme sua posição social e pecado em vida. O prazer experienciado em vida torna-se sofrimento no além, cuja 
teatral encenação é descrita de tal forma, que a audiência pode se imaginar na plateia e se flagrar gargalhando como demônios.

\section{REFERÊNCIAS BIBLIOGRÁFICAS}

BAKHTIN, Mikhail Mikhailovitch. A cultura popular na Idade Média e no Renascimento: o contexto de François Rabelais. São Paulo: HUCITEC, 1987.

Forense Universitária, 1981.

Problemas da poética de Dostoievski. Rio de Janeiro: São Paulo: UNESP, 1998.

Questões de literatura e de estética: a teoria do romance.

BÍBLIA - Tradução Ecumênica da Bíblia. São Paulo: Loyola, 1994.

COLLINS, John Joseph. The apocalyptic imagination: an introduction to Jewish apocalyptic literature. Grand Rapids: Eerdmans, 1998.

DISCINI, Norma. Carnavalização. In: BRAIT, Beth (org.). Bakhtin: outros conceitos. São Paulo: Contexto, 2006, p. 53-93.

FRANCO JÚNIOR, Hilário. A Idade Média: nascimento do ocidente. São Paulo: Brasiliense, 2001. 2008 .

FIORIN, José Luiz. Introdução ao pensamento de Bakhtin. São Paulo: Ática,

GOLIN, Luana Martins; WOTCKOSKI, Ricardo Boone. O além-mundo no imaginário medieval: a visão de Thurkill. In: NOGUEIRA, Paulo Augusto de Souza. (org.). $O$ imaginário do além-mundo na apocalíptica e na literatura visionária medieval: itinerários de recepção. São Bernardo do Campo: UMESP, 2015, p. 243-266.

LE GOFF, Jacques. Em busca da Idade Média. Rio de Janeiro: Civilização Brasileira, 2005. ${ }^{20}$ .et al. O homem medieval. Lisboa: Editora Presença, 1989.

MACHADO, Irene. A. Narrativa e combinatória dos gêneros prosaicos: a textualização dialógica. Itinerários - Revista de Literatura. Araraquara, n. 12, p. 33-46, 1998.

MORGAN, Alison. Dante and the Medieval Other World. New York: Cambridge University Press, 2007.

POTTHOFF, Stephen. E. The Afterlife in Early Christian Carthage: Near-death Experience, Ancestor cult, and the Archaeology of Paradise. New York: Routledge, 2017.

Visão de Thurkill. Tradução de Ricardo Boone Wotckoski. Brathair. Revista de Estudos Celtas e Germânicos, São Luís (UEMA), v. 13., n. 2, p. 138-147, 2013. 
${ }^{1}$ Poeta grego que teria vivido no século VIII a.C. e a quem se atribui a autoria dos poemas épicos Ilíada e Odisseia.

${ }^{2}$ Considerado um dos maiores poetas de Roma, Virgílio viveu entre 70 a.C. e 19 a.C. Sua obra de maior relevo é Eneida, epopeia que consolida a lendária descendência dos romanos dos troianos, por meio de Enéias, um dos heróis da Ilíada.

${ }^{3}$ Plutarco 46 d.C. e 120 d.C.), filósofo grego, ficou conhecido sobretudo por causa de suas obras Vidas Paralelas e Moralia.

${ }^{4}$ Intervalo de tempo entre o último escrito considerado canônico do Antigo ou Primeiro Testamento e o Novo ou Segundo Testamento.

${ }^{5}$ Conheço um homem em Cristo que, faz quatorze anos - era no meu corpo? não sei; era fora do meu corpo? não sei. Deus o sabe - este homem foi arrebatado ao terceiro céu. E sei que este homem - era em seu corpo? era sem o seu corpo? não sei. Deus o sabe - este homem foi arrebatado ao paraíso e ouviu palavras inexprimíveis que não é permitido ao homem repetir (Bíblia - Tradução Ecumênica, 1994, p. 2245).

${ }^{6}$ O papa Gregório I, também conhecido com Gregório Magno, foi papa de 590 até sua morte em 604 d.C, e seus textos são os principais responsáveis por sua notoriedade.

7 Escritos dos primeiros séculos do cristianismo que, embora tenham gozado de popularidade e influenciado o imaginário de certos grupos, por algum tempo, não foram reconhecidos como canônicos ou inspirados por Deus e, portanto, não fazem parte da Bíblia. Isso deu-se já no século IV de nossa era.

${ }^{8}$ Roger Wendover é considerado o primeiro grande cronista da abadia de São Albanio. Flores Historiarum, obra em que relata sua versão da Visão de Thurkill, tem a ambição de cobrir o período entre a criação do mundo e o ano anterior a sua morte, 1235. Em 1841, H. O. Coxe editou Flores Historiarum em cinco volumes, mas apenas as crônicas do ano de $447 \mathrm{em}$ diante, pois, a partir desse ponto, Wendover faz referência pela primeira vez à história da Bretanha.

${ }^{9} \mathrm{O}$ cair da noite é significativo nesse relato por fazer parte do horário reservado às orações vespertinas.

${ }^{10}$ De acordo com a hagiografia, São Juliano seria Simão, o leproso, que hospedou Cristo em sua casa. Semelhantemente, Thurkill é descrito como hospitaleiro e também recebeu o santo em sua casa.

${ }^{11}$ Conforme o texto bíblico de Atos dos Apóstolos 12,1-2, São Tiago morreu como mártir, decapitado a mando do rei Herodes. A tradição hagiográfica diz que seu corpo foi transladado a Compostela, na Galícia, atual região da Espanha. O local passou a chamar-se Santiago de Compostela. Peregrinações camponesas ao local eram comuns.

${ }^{12}$ Uma provável referência à Basílica Papal de Santa Maria Maggiore, primeira igreja de Roma dedicada à Virgem Maria.

${ }^{13}$ Provavelmente São Domingos, fundador da Ordem dos Dominicanos, que enviou pregadores à Inglaterra.

${ }^{14}$ Como também era chamado o purgatório na Idade Média.

${ }^{15}$ Provavelmente São Nicolau de Mira, também conhecido como São Nicolau de Bari. É o santo padroeiro da Grécia, Noruega e Rússia. Patrono dos guardas noturnos e dos coroinhas.

${ }^{16} \mathrm{Na}$ tradição cristã, São Miguel Arcanjo é o príncipe da milícia celeste, que combateu no céu contra o dragão e seus anjos (Apocalipse 12,7). Além de combater Satanás e os poderes do mal, tem a tarefa de proteger o povo de Deus, especialmente na hora da morte.

${ }^{17}$ Ao inserir a balança no julgamento das almas, a visão retoma um elemento presente no imaginário do Antigo Egito sobre o além-mundo, quando diante de Osíris e outros seres transcendentes, a alma participava de um rito de pesagem de suas faltas. A pesagem das almas numa balança é referenciada também no Antigo Testamento, no Livro de Daniel 5, 27, por Santo Agostinho, e representada na iconografia medieval. O redator a vincula aos pais da Igreja, numa tentativa de dialogar com a doutrina oficial da Igreja.

${ }^{18}$ Patriarca do Antigo Testamento, considerado o pai da fé, cujo seio aparece no Evangelho Segundo Lucas 16, 19-31 (a narrativa do rico e do lázaro) como lugar de repouso dos salvos.

${ }^{19} \mathrm{O}$ inferno torna-se uma combinação de elementos presentes em outras culturas. $\mathrm{O}$ inferno dos egípcios, por exemplo, abrigava fossos de fogo, abismos escuros, foices, rios de água fervente, exalações fétidas, dragões cuspidores de fogo, monstros assustadores e criaturas com cabeças de animais, características essas que se tornaram típicas das descrições cristãs medievais do inferno e de seus castigos. 